\title{
ALGUMAS CONSIDERAÇÕES SOBRE A INFLUENCIA DO PENSAMENTO DE HUGO GROTIUS NO DIREITO INTERNACIONAL CONTEMPORÂNEO
}

\author{
Leonam Baesso da Silva Liziero'
}

\section{Resumo}

O artigo apresentado descreve algumas das influencias do pensamento racionalista do jurista holandês de Hugo Grotius (1583-1645) no direito internacional contemporâneo, que ainda permanecem, mesmo após a entrada em vigor do sistema Nações Unidas, em substituição ao sistema clássico de direito internacional, o de Westphalia. Para isso, são apresentadas algumas considerações iniciais sobre o que foi a Guerra dos Trinta Anos (1618-1648), estopim de uma tensão política entre católicos e protestantes provinda do século anterior, e seu resultado, a Paz de Westphalia, um divisor de águas na história do direito internacional. Posteriormente se falará sobre o pensamento racionalista de Grotius, sua inovação ao pensar um direito natural imutável independente do direito divino e como pensou a questão da justiça na guerra. Por fim, será discutido como algumas ideias jusracionalistas de Grotius podem ser encontradas na configuração do direito internacional contemporâneo, com ênfase na característica de (quase) imutabilidade do jus cogens e no sistema de segurança coletiva da Organização das Nações Unidas.

Palavras-chave: Hugo Grotius; Direito Internaiconal; Jusracionalismo.

\section{INTRODUÇÃO}

Quando Grotius escreveu suas obras, os vestígios do poder supranacional que tanto marcaram a Europa na Idade Média tinham quase que desaparecido. Exemplos claros disso são a Igreja Católica Apostólica Romana em relação aos soberanos de grande autoridade medievais e o grande potentado do Sacro Império Romano Germânico.

\footnotetext{
${ }^{1}$ Doutorando em Teoria e Filosofia do Direito pela Universidade do Estado do Rio de Janeiro - UERJ. Professor da Universidade Candido Mendes-UCAM. E-mail: leonamliziero@gmail.com vol.08, nº. 01, Rio de Janeiro, 2015. pp. 81-105 
O continente estava em processo de conclusão de um longo período de guerras, que levaram ao surgimento de pequenos Estados. Esta sucessão de mudanças conduziu depois de algum tempo à constituição dos grandes Estados do continente europeu, que teve início com o juramento de vassalagem de Afonso Henrique ao Vaticano em 1139, tornando-se assim o rei do Estado de Portugal e que terminou com as revoluções de unificação da Itália e da Alemanha no século XIX. Estas alterações das relações internas e externas do sistema político da Europa provocavam descontentamento nos próprios países, já que era interessante para eles realizar um equilíbrio político regional.ssim, vemos que Hugo Grotius viveu em um período em que as guerras eram uma constante, um meio comum de resolver divergências políticas; as grandes potências da época (França, Espanha, Inglaterra, Suécia e o Sacro Império Romano) estavam sempre de prontidão para dar início à um conflito, fosse por um motivo realmente grave ou por meras futilidades políticas.

Hugo Grotius ${ }^{2}$ nasceu em Delft, no dia 10 e abril de 1583 e faleceu em Rostock, dia 28 de agosto de 1645. Doutorou-se em Direito na Universidade de Orleans. Em 1599, começou a exercer função de jurista em Haia. Cinco anos depois, tornou-se conselheiro jurídico do príncipe holandês Maurício de Nassau. Em 1613, foi nomeado governador de Rotterdam, e em 1617 tornou-se membro do Comitê de Conselheiros do Partido Arminiano. Em Agosto os Estados Gerais iniciaram um conflito com a Holanda, futuramente calvinista. Em 1618, após um inesperado golpe de Estado calvinista, foi preso com van Oldenbarnevelt e Rombout Hoogerbeets (pensionário de Leyden) em nome dos novos Estados Gerais. Por ter dado apoio ao parlamento holandês e van Oldenbarnevelt na luta pelo poder contra Maurício de Nassau, acabou preso. Em 1619, foi sentenciado à prisão perpétua trancafiado no castelo de Loevestein acusado de traição. Não tendo outra saída, auxiliado pela esposa, escapuliu do confinamento dentro de uma arca que continha alguns livros, dali seguiu foragido para Amsterdam e em seguida, Paris. Em 1625, publicou O Direito da Guerra e da Paz. Serviu à Coroa Sueca como embaixador.

\section{A GUERRA DOS TRINTA ANOS E O DIREITO DA GUERRA E DA PAZ}

\footnotetext{
2 Para informações sobre a vida de Grotius, conferir KINGSBURY, Benedict; ROBERTS, Adam. Introduction: Grotian Thougth in International Relations. In: BULL, Hedley; KINGSBURY, Benedict; ROBERTS, Adam. Hugo Grotius and International Relations. Clarendon Paperbacks, 1992, pp.1-64. vol.08, nº. 01, Rio de Janeiro, 2015. pp. 81-105 82
} 
A reforma protestante, iniciada com Lutero, foi contida em 1555 pela Paz de Augsburg. Este tratado determinou as zonas de influencia católicas e luteranas de acordo com a religião do governante local. Não era uma solução em longo prazo, mas durante pelo menos cinquenta anos prevaleceu como lei válida. Interessados no controle do mar Báltico, suecos e dinamarqueses provocaram novas tensões, encorajando assim os protestantes alemães. Enquanto isso, os Habsburgos procuravam se infiltrar na França, mas o rei francês, Henrique IV, retaliando, apoiou os protestantes das outras nações.

A Espanha, querendo retomar a região da Holanda, financiou a repressão aos protestantes. Assim, com a Defenestração de Praga, A Europa explodiu no conflito brutal em 1618. O ano de 1618 foi como muitos outros nestas difíceis décadas de neutralidade armada que ocorreram de tempos em tempos na história da Europa. Distúrbios políticos explodiram intermitentemente no clima tenso com medo de novos violentos conflitos. Diplomatas estavam receosos, enfrentando a gravidade de cada nova manifestação violenta e repentina de ruptura de equilíbrio, com políticas precipitadas. Enquanto estes negociadores dos Estados encaravam estas crises, quarenta milhões de camponeses inseridos numa estrutura confusa da estática civilização viviam em meio a campos de batalha.

A Guerra dos Trinta anos foi sem sombra de dúvida uma real catástrofe para todo o continente europeu. Catástrofe causada sim, além das contas. Homens da Europa geraram esta calamidade para eles próprios. Conhecida como um conflito armado entre católicos e protestantes, se originou graças à ambição dos Habsburgos em obter o controle político em todo território germânico, senão todo europeu. Acabou por fixar a divisão religiosa da Europa até os tempos atuais. Nas palavras de C.V. Wedgwood, esta guerra foi "moralmente corrupta, economicamente destrutiva. Uma degradação para a sociedade"3

Era claro no conflito a divisão de dois polos distintos, porém modificações aconteceram nas alianças internacionais no centro da Europa em razão de antigas rivalidades entre os países, como a Holanda que queria se libertar da Espanha, que por sua vez tinha histórico de lides com a França. Os franceses, como de se esperar,

\footnotetext{
${ }^{3}$ WEDGWOOD. The Thirty Years War. New York: New York Review Book, 2005, p. 78
} 
por ambicionarem a supremacia política do continente, eram rivais dos austríacos. Também já existiam alguns conflitos internos entre os principados católicos e luteranos do Sacro Império.

Eram os polos do conflito: (a) Os católicos: Eram comandados pelos Habsburgos. A família Habsburgos era a qual pertencia Fernando II, rei da Hungria, Áustria e Estíria, eleito imperador do Sacro Império Romano Germânico em 1619, posteriormente sucedido por seu filho, Fernando III. Formavam uma aliança com as nações católicas da Germânia e tinham parentesco com o rei espanhol Felipe III (sucedido por Felipe IV). Além de serem da mesma dinastia, os soberanos do Sacro Império e a Espanha eram fervorosamente católicos e recebiam o apoio do papa. Por alguns períodos, este bloco católico foi apoiado por luteranos da Saxônia e calvinistas de Brandeburgo. O objetivo desta aliança católica era abolir a crença protestante do solo europeu. (b) Os protestantes: A aliança protestante era constituída de diversas regiões da Germânia, como a Boêmia, Brandeburgo, Saxônia, o Palatinado do rei Frederico V (que em 1620, após a derrota para Fernando II, se refugiou na Holanda); a Dinamarca; a Suécia do rei Gustavo Adolfo, mais tarde sucedido por Cristina; a Inglaterra (que não teve participação significativa no conflito), a Holanda, que era governada pela casa de Nassau; e a França, país católico que por interesse político e econômico apoiou os protestantes e entrou definitivamente na guerra entre 1634 e 1635. Este bloco tinha o objetivo de lutar pelos direitos dos luteranos e calvinistas, para que fosse reconhecida a liberdade religiosa (a França tinha como fim alcançar o poder supremo do continente enfraquecendo seus dois grandes rivais: a Espanha e o Sacro Império).

Além desta divisão em polos, cada um dos beligerantes envolvidos buscavam seus próprios interesses privados e havia até mesmo conflitos entre integrantes do mesmo lado como a Suécia e Dinamarca.

Um dos principais traços que caracterizam a obra de Grotius foi a tentativa de levar o aspecto internacional a um equilíbrio aonde não haveria conflitos, resgatando a paz e organizando regras de condutas a serem seguidas pelos Estados no relacionamento entre eles. Pode-se, ao realizar a leitura de O Direito da Guerra e da Paz, encontrar alguns objetivos aspirados pelo jurista holandês: a dessacralização do princípio da guerra, assim como sua condenação. A guerra só seria ainda admitida caso fossem respeitados determinados limites; a valorização dos Tratados; a instituição 
de um ordenamento e engrandecer uma técnica essencialmente jurídica entre os Estados, o Jus Gentium; a busca de meios para, nas situações em que fosse necessário, manter ou reestabelecer a paz; a limitação das guerras às partes diretamente envolvidas, gerando assim aos outros países não envolvidos uma condição de neutralidade e; a elaboração de uma teoria que favorecesse o desenvolvimento progressivo da sociedade internacional como uma entidade constituída por Estados soberanos.

Após a terrível calamidade que envolveu a Europa por trinta anos em choque religioso, os países finalmente decidiram pela paz. Assim como muitas guerras que terminam com um tratado de cessação de hostilidades, a Guerra dos Trinta Anos se resolveu com um deles: A Paz de Westphalia de 1648. Um grande marco para o Direito. A instituição do Jus Gentium, do princípio da territorialidade e enfim, a concepção do Estado moderno.

Um ente soberano que governa uma ordem jurídica própria em um espaço terrestre, marítimo e aéreo com fronteiras admitidas pelo Direito Internacional, para um povo que vive neste determinado espaço.

A partir de então, o relacionamento entre Estados seria regido por normas jurídicas criadas entre eles. A constituição de um Direito comum a todos os povos, que seria formulado pelos Estados e teriam eles próprios como destinatários de regras a serem cumpridas.

\section{A PAZ DE WESTPHALIA}

A Paz de Westphalia consagrou o princípio hujus regio, ejus religio. Em sua literal tradução: "na região dele, a religião dele".

Em uma profunda análise do que dita o princípio, significa que em um determinado território, sob a autoridade de um governante, deve imperar uma única ordem jurídica definida por ele. Deste modo, vemos que o sentido de religio é muito mais voltado para a imposição de um ordenamento jurídico laico e técnico do que tornar obrigatório a religião escolhida por aquele que governa o Estado. 
Grotius, utilizando os ensinamentos de Tito Lívio, nos faz conhecer que "os tratados são aqueles que se fazem por ordem do poder soberano e nos quais o próprio povo fica exposto à ira divina se faltou com sua palavra." 4

Vemos assim que esta frase de Grotius pode sintetizar quilo que serviu de base para a aplicação hujus regio, ejus religio no Tratado de Paz de Westphalia. Se o Estado descumprisse aquilo a que se obrigou com o tratado, sofreria uma sanção superior ao âmbito nacional. Podemos perceber que neste sentido, "ira divina", é a punição ao Estado que deixou de cumprir a obrigação (seja um dar, fazer ou não fazer) realizada pelos outros Estados signatários.

Desta forma, apoiado em uma base contratual, Grotius formulou uma teoria em que os Estados deviam ser signatários de um pacto intergovernamental que os obrigasse e que imperasse entre eles uma relação de confiança. Para atender ao que o tratado estabelecesse, os Estados precisariam sacrificar um pouco da sua soberania em prol da norma superior (norma do direito das gentes)

Para que a Paz de Westphalia fosse realizada, foram escolhidas duas cidades germânicas declaradas como zonas neutras em acordo pelos beligerantes: as cidades de Osnabrück e Münster. Nos encontros de negociação, são reunidos, segundo informações da época, representantes de quase 200 países, entre eles, grandes potências, ducados, condados e principados. Dos grandes Estados, não aparecem para serem partidários a Inglaterra, o Império Otomano e a Rússia.

Os católicos se reúnem em Münster. Os protestantes, em Osnarbrück. Ao final das negociações, a França, dirigida por Mezarino, consegue o domínio sobre os territórios da Alsácia, Philippsburg e Breisach., além de manter o que tinha conquistado da Espanha na guerra: Flanders, Roussilon e Artois. Contudo, o principal objetivo da França é alcançado: o enfraquecimento da Dinastia Habsburgo. A Suécia, grande vencedora da Guerra dos Trinta Anos junto com França e Holanda, consegue terras no norte da Alemanha, como por exemplo, a Pomerânia. A Holanda, após anos tentando se libertar da Espanha, consegue enfim sua independência. É criada a Confederação da Suíça.

\footnotetext{
${ }^{4}$ 3GROTIUS, Hugo. O Direito da Guerra e da Paz. Ijuí: Unijuí, 2007,p 65o.
} 
As primeiras sentenças do Tratado de Westphalia afirmam que a paz deve ser “cristã, universal, perpétua e que ela seja uma amizade verdadeira e sincera entre todas as partes". ${ }^{5}$ Deste modo, como imaginou Grotius, este tratado foi uma estabilidade conseguida pela confiança mútua entre as partes. Sem a interferência da Santa Sé no Tratado, a Paz de Westphalia era uma obrigação civil entre os governantes que eram simultaneamente como magistrados e partes.

Em relação ao âmbito religioso, foram aceitos definitivamente o luteranismo e o calvinismo como confissões consentidas, ou seja, todos os governos que pactuaram o tratado deveriam tolerar o culto de qualquer religião cristã em seu território. Quaisquer que fossem as disputas entre as religiões, deveriam ser resolvidas em negociações diplomáticas. Sobre a evolução da diplomacia com a Paz de Westphalia, ensina Celso D. Albuquerque Mello: "A partir de 1648, a diplomacia passou por diversas transformações e os seus institutos foram se sedimentando. De uma regulamentação consuetudinária chegou-se à regulamentação convencional.”

É importante também destacar que com a elaboração do texto do Tratado de Westphalia, foram redefinidos os critérios de atribuição de nacionalidade, que são conhecidos por jus soli e jus sanguinis. ${ }^{7}$

Além então de uma um marco para o ser do Estado, o Tratado de Westphalia representou um marco para o Direito Internacional, para a diplomacia e para a laicidade do governo.

A região da Alemanha após a Guerra dos Trinta anos ficou em frangalhos. $\mathrm{O}$ conjunto que compunha a forte unidade política do Sacro Império se esfacelou. O poder político do Imperador ficou drasticamente reduzido, já que as cláusulas da Paz de Westphalia deram soberania a diversas regiões que eram partes do Sacro Império, ficando assim o imperador apenas como um administrador de uma confederação. Estes pequenos Estados tinham liberdade de se relacionar com outros estrangeiros

\footnotetext{
${ }^{5}$ ROMANO, Roberto. A Paz de Vestfália (1648) In: Demétrio MAGNOLI. (org.). História da Paz. São Paulo: Contexto, 2007,.p.83.

${ }^{6}$ MELLO, Celso D. de Albuquerque. Curso de Direito Internacional Público. vol.2 13 ed...Rio de Janeiro: Renovar, p 1310.

${ }^{7}$ FILOMENO, José Geraldo Brito. Manual de Teoria Geral do Estado e Ciência Política, $3^{\circ}$ ed. Rio de Janeiro: Forense Universitária,1999, p.67
} 
(França ou Inglaterra, por exemplo), desde que suas ações não fossem lesivas ao Império.

Com tudo isso, Westphalia é tido como o tratado pioneiro com o intuito de proteger a soberania dos Estados, em que a ordem jurídica, política e administrativa de um não deveria intervir na do outro e a separação do mundo religioso e do mundo civil.

\section{O DIREITO DA GUERRA E A RACIONALIZAÇÃO DO DIREITO NATURAL}

A dessacralização da guerra, a relação de confiança entre soberanos e uma ordem jurídica comum entre todos os países constituída de tratados nos quais seriam signatários os próprios Estados, foram ideais que Grotius pretendia que fossem colocados em prática para dar fim à terrível realidade da primeira metade do século XVII. Sua ideia de guerra era uma junção do ser e do agir, que seria um estado em que se encontram os indivíduos que resolvem suas controvérsias usando a força. ${ }^{8}$

Em sua obra encontramos alguns conceitos que se tornaram essenciais para a conclusão do Tratado de Westphalia. Inicialmente Grotius inicia definindo o que seria a guerra: "é o estado de indivíduos, considerados como tais, que resolvem suas controvérsias pela força”. ${ }^{9}$

E juntamente com o Direito e com a guerra, Grotius procurou relacionar estes dois elementos essenciais para as sociedades com outro elemento que está no mais íntimo de cada ser humano: a Justiça. O Direito e a Justiça em o Direito da Guerra e da Paz podem ser fortemente ligados quanto o Direito é considerado aquilo que é justo ou aquilo que não é injusto. E o justo se define pela exclusão do que é apresentado como seu oposto: injusto é tudo que é repugnado pelos seres que podem raciocinar e ponderar ideias universais. Sobre a justiça na guerra, Grotius escreveu ser preciso uma violação ao jus gentium para que nela houvesse alguma justiça. E nesse caso, apoiando-se em autores como Sêneca, defende "três causas legítimas da guerra: a defesa, a recuperação do que nos pertence e a punição" . ${ }^{10}$ Com o passar do tempo suas

\footnotetext{
${ }^{8}$ GROTIUS, Hugo. O Direito da Guerra e da Paz. Ijuí: Unijuí, 2007,p. 101.

${ }^{9}$ Ibidem, p. 73

${ }^{10}$ Ibidem, p.287
} 
concepções sobre guerra justa foram aprimoradas e atualmente é uma questão de suma importância nas relações intergovernamentais.

Segundo esta noção, na atual tutela do Direito Internacional Público aos casos de guerra, é possível perceber alguma influência do jusnaturalismo de Hugo Grotius. Se o homem por sua essência tende a se manter em no estado dado pela natureza, ou seja, se proteger, é natural que ataque àquele que ameace sua integridade."

Deste modo, um Estado formado por uma sociedade que por sua vez é formada por homens tem o direito de guerrear (jus ad bellum) para se defender, com a finalidade de que não haja sua destruição e também para a proteção da ordem soberana vigente em seu território.

A agressão só é considerada justa e de direito quando há uma agressão anterior ilegal contra aquele Estado. Assim, vemos que não é justo o conflito armado que resulta na agressão por uma ameaça não concretizada. Guerra preventiva não pode ser considerada legal, pois não há a agressão efetiva de outro Estado. Pelo que é estabelecido pelo jus cogens sobre a dessacralização do princípio da guerra, o Estado agressor realizar uma ofensiva a outro alegando que este representa uma ameaça não obedece à legalidade intergovernamental, pois perante o Direito Internacional apenas as guerras defensivas são legais.

Sobre a chamada guerra preventiva, Grotius observa o temor de uma coisa incerta não pode dar direito à execução de medidas violentas. A guerra deve ser permitida num perigo presente e certo e não num pressuposto perigo. Com isso, a ameaça deve ser certa e concreta para que o Estado revide. E também como queria Grotius, a guerra deve ser permitida apenas contra o Estado agressor. Recorre-se a ela como um último recurso. Deste modo, ficam excluídos do perigo aqueles que não estiveram envolvidos no conflito, criando o estado de neutralidade. Mesmo se agredido, um Estado deve recorrer aos meios possíveis para resolver o litígio, pleiteando se necessário à Sociedade Internacional a aplicação de alguma sanção antes de recorrer à guerra. $\mathrm{O}$ conflito deve ser dirigido contra aqueles estados que não se submeterem ao que é decidido pela Sociedade Internacional A única causa legítima para guerra é uma agressão violenta recebida. E a guerra pode ser lícita se tiver o Estado tiver o

\footnotetext{
${ }^{11}$ Ibidem, p. 297
} 
intuito de se defender ou recuperar algo que lhe foi injustamente tomado por outro Estado.

Sobre o sentido do termo direito, ensina Grotius que o primeiro se relaciona à justiça, "o Direito pode ser aquilo que é justo ou aquilo que não é injusto e, injusto é tudo aquilo que é repudiado pelos seres dotados de razão."12. Seguindo este raciocínio, em um segundo sentido, Grotius afirmou que o "Direito é uma qualidade moral do indivíduo para possuir ou fazer de modo justo alguma coisa."13

No sentido mais trabalhado por Grotius, o terceiro, o direito tem um significado amplo de lei. O direito nesse sentido é tido numa compreensão racionalista, dividindose em direito natural e direito voluntário. $\mathrm{O}$ direito natural permite uma legitimação do direito voluntário, mas agora não mais em bases de cunho cosmológico ou teológico, mas sim baseados na capacidade de conhecimento humano.

Nesse sentido, "o direito natural nos é ditado pela razão que nos leva a conhecer que uma ação, dependendo se é ou não conforme à natureza racional, é afetada ou não pela deformidade moral ou por e necessidade moral e que, em decorrência, Deus, o autor da natureza, a proíbe ou a ou a ordena". ${ }^{14}$

Grotius defende a imutabilidade do direito natural:

O direito natural é tão imutável que não pode ser mudado nem pelo próprio Deus. Por mais imenso que seja o poder de Deus, podemos dizer que há coisas que ele não abrange porque aquelas de que fazemos alusão não podem ser senão enunciadas, mas que não possuem nenhum sentido que exprima uma realidade e são contraditórias em si. Do mesmo modo, portanto, que Deus não poderia fazer com que dois mais dois não fossem quatro, de igual modo ele não pode impedir que aquilo que é essencialmente mau não seja mau. [...] na realidade não é o direito natural que muda, sendo imutável, mas é a coisa, a respeito da qual o direito natural estatuiu, que sofre mudança. ${ }^{15}$

Essa concepção de direito natural fundamenta o direito na razão humana independente da figura divina, fundamento do direito natural no medievo. Conforme Wight,

\footnotetext{
${ }^{12}$ Ibidem, p. 72

${ }^{13}$ Ibidem, p. 74

${ }^{14}$ Ibidem, p. 81

${ }^{15}$ Idem
} 
Grotius viu o direito natural como sendo racional, isto é, totalmente aberto à exploração pela razão e reduzível a uma forma sistemática. $\mathrm{O}$ direito natural é baseado na natureza dos seres humanos, não, como em outras leis, por sua vontade, nem diretamente pela vontade de Deus; mas abrange assuntos decorrentes da vontade humana. ${ }^{16}$

Este jusracionalismo é uma característica da concepção moderna do direito e posteriormente culminará com a percepção dos direitos naturais individuais dados pela razão humano no Século XVIII. Para France Farago, "é preciso compreender a máxima de Grotius que diz que todas as teses do direito natural poderiam conservar sua validez admitindo mesmo que não tivesse existido nenhum Deus, ou que a própria divindade não se preocupasse com o mundo das coisas humanas" ${ }^{\text {17 }}$

Pelos preceitos da época, os Estados Católicos consideravam justa a agressão aos protestantes (inclusive a ruptura da Paz de Augsburgo de 1555). Encontravam a legalidade para seu ato no incidente diplomático conhecido como a "Defenestração de Praga”, em que dois representantes católicos do imperador Matias em Praga foram jogados pela janela pelos protestantes.

Além do conflito religioso entre cristãos, a guerra também foi levada à tona pelos interesses dos Habsburgos que desejavam manter o poder do Império, e pelos interesses dos outros Estados em esfacelar o poder do Sacro Império cada vez mais; a luta de independência da Holanda contra a Espanha e outras razões particulares de algumas nações.

Com o fim da guerra, o Direito Internacional ganhou real amplitude. A Paz de Westphalia de 1648 atendeu aos objetivos da obra de Grotius. Formou-se entre os signatários e consequentemente aos demais Estados a instituição e amplificação de uma ciência dedicada ao estudo de relações entre os Estados, o jus gentium. Neste sentido, leciona Floh:

Nesse momento observa-se não apenas a revisão da Ordem Internacional e dos parâmetros tradicionais das relações internacionais, mas também o estabelecimento

\footnotetext{
${ }^{16}$ WIGHT, Martin. Four Seminal Thinkers in International Theory: Machiavelli, Grotius, Kant and Mazzini. New York: Oxford University Press, 2005, p.39. No original em inglês: "Grotius saw natural law as being rational, that is, wholly open to exploration by reason and reducible to a systematic form. Natural law is based on the nature of human beings, not, like other laws, on their will, nor directly on the will of God; but it covers matters resulting from human will."

${ }^{17}$ FARAGO, France. A Justiça. Barueri: Manole, 2005, p. 165.
} 
de novas bases para o sistema de normas de Direito Internacional, ou seja, o surgimento de uma nova ordem jurídica, tal como proposto na obra clássica e H.Grotius, alguns anos antes da Paz de Vestfália. ${ }^{18}$

Sendo um instituto jurídico, o jus gentium deve regular as ações de um estado frente ao outro, com uma relação de confiança entre os soberanos. Deste modo, sendo respeitado o Princípio da Territorialidade, os governantes confabulam-se com os outros, seja para determinar regras comuns a serem aplicadas dentro da ordem jurídica interna de cada um, seja para a resolução de conflitos de interesses devendo priorizar a solução pacífica das divergências.

O princípio de que uma ordem jurídica deve ser eficaz para ser válida é pertencente ao Direito Internacional. Por este princípio, uma autoridade efetivamente investida é o governante legítimo, a ordem coercitiva decretada por este poder soberano é a ordem jurídico- administrativa que paira em um determinado território no qual vive uma sociedade é um Estado reconhecido internacionalmente, na proporção em que essa soberania é, como um todo, eficaz.

\section{INFLUÊNCIAS NO DIREITO INTERNACIONAL CONTEMPORÂNEO}

As normas fundamentais de várias ordens jurídicas internas de um Estado são fundamentadas em normas gerais de Direito Internacional Público, sejam elas geradas por tratados-leis, tradados-contrato, atos unilaterais das nações, costumes, decisões das Cortes Internacionais ou ainda, pelo jus cogens. É de grande importância também conceituar o jus cogens como sendo os princípios gerais do Direito internacional Público; é contrário aos atos terroristas, ao narcotráfico e outros atos que atrapalhem a ordem e estabilidade dos Estados, além da proteção à pessoa humana. O jus cogens deve ter sempre um caráter geral em relação aos Estados tutelados pelo direito internacional. Neste sentido,

Se jus cogens deve refletir normas fundamentais para estruturar a Sociedade Internacional, os valores a ela mais caros e que sejam de um entendimento geral, entre todas as fontes, apenas um tratado multilateral que tenha um alto numero de Estados signatários com grande

\footnotetext{
18 FLOH, Fabio. Direito Internacional Contemporâneo:Elementos para a Configuração de um Direito Internacional na Ordem Internacional Neo-Vestfaliana. In: CASELLA, Paulo Borba. et al.(org.) Direito Internacional, Humanismo e Globalidade. São Paulo: Atlas, 2009, p. 220. 
relevância para o cenário internacional podem instituir tais normas. ${ }^{19}$

Pode-se dizer inclusive que é um polo de normas imutáveis que está acima de todas as outras e que até mesmo os tratados internacionais serão nulos se regularem matéria contrária ao jus cogens. A prescrição normativa sobre este tema se encontra na Convenção de Viena Sobre Direitos dos Tratados de 1969, em seu artigo 53. Sobre a obrigatoriedade, explica Jete Jane Fiorati,

A imperatividade do jus cogens não implica somente na sua obrigatoriedade, uma vez que também as normas derivadas de jus dispositivum são obrigatórias para as partes, mas, principalmente, na proibição da derrogação de suas normas. A imperatividade encontra sua outra face na inderrogabilidade. ${ }^{20}$

Possível seria então a criação de uma norma que vincularia seus Estados signatários a aceitar a guerra como ilícito internacional? É uma das funções da Carta das Nações Unidas, que entrou em vigor em 24 de outubro de 1945, tratado este considerado um tratado- constituição. Interessante completarmos este raciocínio com um as palavras de Paulo Borba Casella, ${ }^{21}$ utilizando-se dos ensinamentos de Vicente Marotta Rangel, ainda que se tratando de questão terminológica: “Texto constitucional da sociedade internacional' -na expressão de Vicente Marotta RANGEL (1954)-, o tratado hierarquicamente mais importante é a Carta, expressão utilizada no tocante às Nações Unidas.”

Percebe-se então que numa sociedade composta por Estados, há a necessidade da criação de normas para se protegerem um dos outros. No caso da Carta da ONU, houve a concretização de uma tendência de institucionalização do Direito Internacional, que já vinha desde Westphalia. Explica Mazzuoli:

O Direito internacional deixa de ser um direito das relações bilaterias ou multilaterais entre os Estados para se tornar um direito cada vez mais presente nos organismos internacionais, na Organização das Nações Unidas, bem como em suas agências especializadas, podendo até mesmo chegar à criação de um órgão supranacional com poderes decisórios, como é o caso da

\footnotetext{
${ }^{19}$ LIZIERO, Leonam Baesso da Silva. Jus Cogens, Nações Unidas e Direito Bélico. Rio de Janeiro: Agbook, 2013, p. 50.

${ }^{20}$ FIORATI, Jete Jane. Jus Cogens: As Normas Imperativas do Direito Internacional Público como Modalidade Extintiva dos Tratados Internacionais, p.86.

${ }^{21}$ ACCIOLY, Hildebrando; NASCIMENTO E SILVA, Geraldo Eulálio do; CASELLA, Paulo Borba. Manual de Direito Internacional Público. 16ạ. ed. ref. São Paulo: Saraiva, 20o8, p. 132.
} 
União Europeia. $\mathrm{O}$ grau de institucionalização da sociedade internacional pode ser aferido pelo numero de órgãos criados e respeitados pela maioria dos Estados motivados pelo interesse em sedimentar a existência de polos decisórios das relações internacionais ${ }^{22}$

Havendo então instituições de Direito Internacional, há um maior controle de atos dos Estados, uma vez que se obrigam a aceitar as normas internacionais, obrigatoriedade esta fundamentada no princípio pacta sunt servanda. Este princípio de direito internacional por sua vez encontra importância fundamental na obra de Grotius. Segundo o autor, "o dever de cumprir as promessas decorre da natureza da justiça imutável que é comum em sua maneira a Deus e a todos os seres dotados de razão". ${ }^{23}$

Isso implicou no pensamento jurídico internacionalista posterior a obrigatoriedade dos pactos (inclusive na teoria kelseniana) o que se tornou alguns dos fundamentos do contemporâneo Direito dos Tratados, principalmente no princípio do pacta sunt servanda, no qual o tratado faz lei entre os Estados signatários e que o que for pactuado deve ser cumprido e o princípio da boa-fé, que dita que um Estado pactuante tem um dever de lealdade, cooperação e confiança com o outro Estado que venha a participar do acordo (ou outros Estados, caso seja um tratado multilateral)

A força destes dois princípios é tão significativa que são previstos na Convenção de Viena sobre direitos dos Tratados de 1969, em seu artigo 26:“Todo tratado em vigor obriga as partes e deve ser cumprido por elas de boa-fé" Nesta mesma convenção, sobre as regras de interpretação dos tratados também determina o artigo 31 que: "Um tratado deve ser interpretado de boa-fé segundo o sentido comum atribuível aos termos do tratado em seu contexto e à luz de seu objetivo e finalidade”

Com isso é possível resolver muitos conflitos atuais determinando normas entre os beligerantes que atendam aos interesses dos envolvidos. Assim, os desentendimentos religiosos que acontecem constantemente nos países europeus, não apenas em razão do credo como da etnia, poderiam ser resolvidos se realizado um tratado entre a Comunidade Europeia para aceitação das diferenças. Desta forma, os Estados se obrigariam a tolerar a diversidade entre os povos de todo continente, preconizando que para esta tolerância deve haver um comprometimento daqueles

\footnotetext{
${ }^{22}$ MAZZUOLI, Valério de Oliveira. Curso de Direito Internacional Público 3 ed. São Paulo: RT, 2009, p.49.

${ }^{23}$ GROTIUS, Hugo. O Direito da Guerra e da Paz, pp. 551-552.
} 
beneficiados que deverão respeitar as normas internacionais e internas de cada Estado, resolvendo seus litígios, quando houver, de maneira pacífica.

Veja-se que com isso, a valorização do pacifismo e da proteção à pessoa humana traduz um interesse de todos na Comunidade Internacional. É, portanto, necessária uma relação de confiança entre os governos de cada Estado. Já que existe a condenação da guerra, o ideal é que os Estados utilizem as fontes do Direito Internacional alcançarem seus objetivos. E mesmo se o Estado estiver em uma crise interna de conflitos que sejam de plenitude internacional, deve se ater às normas internacionais para a então aplicação de suas leis internas.

Desta forma, segundo os princípios gerais do Direito das Gentes, a guerra é proibida em um primeiro momento. É legítima apenas se for uma reação contra um ato antijurídico ou contra uma agressão armada em nível de Estado, sendo que deve ser dirigida apenas ao Estado responsável pelo delito.

E por diversos motivos, Grotius procurou demonstrar que o direito de natureza não se opõe à guerra, invocando assim a questão do envolvimento na justiça nas guerras que podiam ser legitimadas por este direito natural, "sendo o objetivo da guerra assegurar a conservação da vida e do corpo, conservar ou adquirir as coisas úteis à existência, este objetivo está em perfeita harmonia com os princípios primeiros da natureza" ${ }^{24}$. Esta legitimação encontra sua origem na percepção racional do direito natural que ensina que nos primórdios a guerra tinha como objetivo a preservação da vida e do corpo e proteger ou conquistar aquelas coisas que seriam necessárias à existência. Desta forma, "não é, portanto agir contra a natureza da sociedade zelar e prover para os próprios interesses, sob a condição deque o direito do outro não seja atingido. Em decorrência, o emprego da força, quando não viola direitos de outros, não é injusto." 25

Leciona a este respeito Wight:

Somente a guerra justa é legal e um beligerante envolvido em uma guerra justa pode infligir punição a seu inimigo, e o inimigo (o beligerante injusto) não tem direito de se defender, mas ele admite que, em seguida, na prática, a distinção é desprezivel: uma vez que a guerra tem início,

\footnotetext{
${ }^{24}$ Ibidem, p. 101.

${ }^{25}$ Ibidem, p. 103.
} 
deve ser conduzida de acordo com as regras da guerra sem levar em conta as causas da justiça dela. ${ }^{26}$

Porém temos as situações nas quais certos atos dos Estados causam dano a outro, seja por descumprimento de convenção internacional, seja por quaisquer outras atitudes tomadas. Como a partir da Carta da ONU foi consolidado o instituto da solução pacífica de conflitos internacionais, o Direito Internacional tem meios de resolver lides entre Estados sem a necessidade de guerra. Tal importância alcançou este instituto que foi devidamente positivado em seu Artigo 33.

Assim, quanto à dessacralização da guerra, as ideias de Grotius foram aprimoradas e puderam ser aplicadas em um âmbito mundial, assegurando a responsabilidade, pois com um dano é gerado um vínculo jurídico.

Com a configuração de um ilícito internacional, é gerada a responsabilidade do Estado infrator. Para entender então quando é imputada esta responsabilidade, é preciso a análise de alguns elementos essenciais. Conforme ensina o professor Guido Fernando Silva Soares: ${ }^{27}$

1. Um comportamento em violação de um dever internacional sempre atribuída a um ou mais Estados, que pode ser um ato comissivo ou omissivo;

2. A existência de um dano físico ou moral causado a outros Estados, seu território e bens, ou ainda ao povo deste;

3. Um nexo de causalidade normativa entre o dano e o ilícito, o qual institui um dever de reparar do Estado infrator e cria uma faculdade do estado atingido de exigir uma reparação.

E nestes elementos apresentados é possível perceber os princípios da dessacralização da guerra e a limitação da guerra aos beligerantes envolvidos no conflito, gerando deste modo uma situação de neutralidade a terceiros países.

Ao que é determinado juridicamente como comportamento lesivo de um Estado, é resultante de uma ideia formulada exclusivamente pelo Direito Internacional. A agressão de um Estado por outro é uma violação de direito. É possível classificar os

\footnotetext{
${ }^{26}$ WIGHT, Martin. Four Seminal Thinkers in International Theory: Machiavelli, Grotius, Kant and Mazzini. New York: Oxford University Press, 2005, p. 51. No original em inglês: "Only the just war is legal and a belligerent engaged in a just war may inflict punishment on his enemy, and the enemy (the unjust belligerent) is not entitled to defend himself; 96 but he then admits that in practice the distinction is negligible: once war is in being, it must be conducted according to rules of war without regard to causes or the justice $\mathrm{f}$ it."

${ }^{27}$ SOARES, Guido Fernando Silva. Curso de Direito Internacional Público. p.186.
} 
danos causados ao Estado quanto à gravidade da lesão em (a) atos ilícitos que tornam possível uma restituição a uma situação anterior, em que a reparação do Estado ofensor é justamente devolver ao Estado lesado a situação na qual ele se encontrava antes da lesão; (b) danos morais, aqueles no quais um Estado ofende a honra e a reputação de outro, sendo que para esta ofensa cabe um pedido de perdão para reparar este dano na maioria das vezes e; (c) destruição de uma propriedade de um Estado economicamente valorizada e, se não for possível um retrocesso à situação anterior ao dano, a indenização deve ser monetária na proporção dos bens destruídos.

Quanto ao dano, também é possível distinguir os que são causados diretamente aos Estados e indiretamente, quando causados às pessoas suas jurisdições ou seus bens. Os danos causados ao Estado diretamente correspondem àquelas lesões no que diz respeito à invasão do território, a destruição de algum bem ou ainda uma ofensa à honra e a imagem moral. No segundo caso, a ofensa é contra particulares, sejam pessoas naturais ou jurídicas, que estão protegidos pelo Estado. ${ }^{28}$

É evidente que, nos casos onde o Estado ofensor não se retrata, seja pedindo desculpas formalmente ou pagando devida indenização, ou se o Estado ofendido não aceitar a retratação daquele Estado que o lesa, o incidente entre estes países pode evoluir para o rompimento de relações diplomáticas e em pior hipótese, para o conflito armado.

A Paz de Westphalia foi o primeiro tratado intergovernamental que conseguiu determinar além de outras inovações, normas a serem aplicadas na guerra. Hoje temos regras reconhecidas oficialmente por tratados internacionais realizados principalmente no século XX. Porém mesmo antes do Tratado de Westphalia em 1648, já houve tentativas de aplicar a solução pacífica pelos povos mais antigos. Como observa John Keegan, "a expectativa de um futuro no qual o recurso à guerra seja colocado sob limites racionais não deve nos levar à falsa visão de que não tenha havido limitações no passado"29

É, no entanto, possível pensar que as guerras podem ser explicadas por defeitos em alguns ou em todos os Estados sem acreditar que a mera eliminação dos defeitos

\footnotetext{
${ }^{28}$ GROTIUS, Hugo. O Direito da Guerra e da Paz, p.297

${ }^{29}$ KEEGAN, John. Uma História das Guerras. São Paulo: Cia das Letras, 2006, p. 94. vol.08, nº. 01, Rio de Janeiro, 2015. pp. 81-105
} 
estabeleça a base da paz perpétua. ${ }^{30}$ Como é utópica a eliminação dos defeitos de cada Estado, pois estão fortemente enraizados em sua cultura, a Comunidade Internacional deve estar preparada a qualquer tempo para um conflito entre países, além de se utilizar da tutela do Direito Internacional Público, para que não haja maiores calamidades além do que a guerra oferece.

Segundo Celso Mello:

Com a evolução do DI e o inicio de uma institucionalização da sociedade internacional na nossa matéria passou a ser eminentemente um direito de paz. A guerra deixou de ser uma sanção, ou um modo violente de solução dos litígios internacionais, para ser um ilícito internacional. Um dos fatores que contribuíram para a evolução neste sentido foi a intensificação das relações internacionais e, em consequência, multiplicando as ocasiões para guerras. Diante deste fato os Estados passaram a procurar resolver litígios internacionais de modo pacífico. ${ }^{31}$

Então, sob a tutela do Direito Internacional Público, a guerra é regulamentada, de onde deriva a expressão usada para o conjunto de normas que imperam as ações dos beligerantes, o jus in bello. Assim, é possível declarar com firmeza que a atuação daqueles que são partes em uma guerra sofre limitações, limitações estas formuladas com base nos princípios gerais de Direito Internacional. Há, segundo a doutrina internacionalista ${ }^{32}$, dois princípios básicos que regem o direito bélico.

O primeiro é o princípio da necessidade, para o qual não deve existir limitações à guerra. Assim sendo, em nome dos objetivos a serem alcançados, o beligerante pode utilizar qualquer meio que bem entender para obter a vitória, não respeitando regramento algum. O Estado, como é esperado em uma guerra, precisa utilizar de todos os meios necessários para não ser derrotado, guerreando para assegurar que o inimigo não destrua o ente soberano que o rege, não tome seu território e não destrua sua estrutura social. Desta forma, não importa se houver opróbrio no conflito. $\mathrm{O}$ mais interessante é ter bom êxito na guerra. O que há de extremamente negativo é justamente a negação à submissão que este princípio faz ao regramento bélico. A existência de convenções, acordos e protocolos existentes para amenizar o uso da força

\footnotetext{
$3^{\circ}$ WALTZ, Kenneth N. O Homem, o Estado e a Guerra. São Paulo, Martins Fontes, 2005 p. 105

${ }^{31}$ MELLO, Celso D. De Albuquerque. Curso de Direito Internacional Público.13 ed. p.1431.

${ }^{32}$ MELLO, Celso D. De Albuquerque. Curso de Direito Internacional Público.13 ed. p.1450 vol.08, $n^{\circ}$. 01, Rio de Janeiro, 2015. pp. 81-105
} 
de um Estado com a finalidade de proteger as vítimas inocentes que sempre tem suas vidas destroçadas de nada valeriam e assim, todos os esforços dos Estados civilizados em cuidar da vida humana em geral seriam em vão.

O segundo é o princípio da humanidade, que ensina justamente que o beligerante deve se portar na guerra respeitando exatamente as leis para conflitos armados e tentar prejudicar minimamente o inimigo. $\mathrm{O}$ conflito armado, para este princípio, deve ser resolvido com o mínimo de destruição possível. Ainda que com todo o sistema internacional de proteção á pessoa humana fortalecer a aplicabilidade deste princípio, percebe-se uma grande idealismo em conflito com a realidade de uma guerra, onde soldados feridos e famintos precisam, além de lutar pelo seu país, lutar por sua própria sobrevivência e para garantir suas vidas, não importa o quanto de estrago causado. Isto se tornou uma questão conflitante nestes "últimos anos não só por causa da conveniência militar que frequentemente insiste que ele deve ser ignorado (isso não é novidade), mas porque os métodos de guerra contemporânea [...] torna cada vez mais difícil de distinguir combatentes de não combatentes". 33 Por isso, ao examinar a aplicação do direito na guerra, é necessário fazer um equilíbrio entre estes dois princípios, sabendo que são simultâneos.

Como no direito interno, em que há aplicação de punição àquele que viola uma norma, o Direito Internacional Público possui sanções que visam prevenir contra uma infração às normas do jus in bello. São estas sanções as represálias, que podem ser entendidas como uma retaliação feita por Estados fora inicialmente do conflito que procuram coibir a agressão realizada pelo Estado que desrespeita os regramentos de guerra. Estas represálias levam a outras sanções, como a má imagem do Estado transgressor diante daqueles que se mantiveram neutros, dificuldade em algumas relações comerciais e ressarcimento de danos ao país que foi prejudicado pela infração ao jus in bello. O que é tema de maior debate é se as represálias são atos lícitos ou ilícitos diante o Direito Internacional. Os que defendem as represálias como ato lícito apoiam seu argumento no fato de que o Estado ao utilizá-las, age em prol da Sociedade Internacional, já que é uma resposta a um delito no âmbito internacional. Por sua vez,

\footnotetext{
${ }^{33}$ HIGGINS, Rosalyn.Grotius and the Developtment of International Law in the United Nations Period. In: BULL, Hedley; KINGSBURY, Benedict; ROBERTS, Adam. Hugo Grotius and International Relations. Clarendon Paperbacks, 1992, p. 275
} 
os que consideram a represália como ilícita, observam que a ONU só admite o uso da força nos casos de legítima defesa.

A negação das leis da guerra pelos beligerantes leva ao que, por uma influência de Clausewitz, é chamado de estado de guerra total. Na guerra total, os civis não são respeitados, os efeitos do conflito ultrapassam os territórios dos beligerantes e não distingue os envolvidos dos não envolvidos. Com isso, há a negação de limites estabelecidos por atos jurídicos internacionais que deveriam ser respeitados por aqueles que se envolvem em hostilidades armadas, a guerra total é uma afronta ao Direito Internacional Público. Conforme a lição de Rodrigo Passos, explicando o pensamento de Clausewitz,

A trindade que caracterizaria a guerra real e completaria sua definição como fenômeno total, comportaria três componentes que expressariam suas tendências dominantes. O primeiro componente englobaria uma violência original, uma hostilidade e uma animosidade, considerados como um impulso natural ego, todos ligados ao povo. O segundo componente diria respeito ao jogo de probabilidades e do acaso que movem livre alma criativa, que dependerá das características de seu comandante e de seu exército. Por fim, a subordinação da guerra à política e aos objetivos políticos, assunto de decisão exclusiva do governo de um Estado. ${ }^{34}$

São diversos os efeitos do estado de guerra. Atinge o próprio Estado, como também as pessoas que nele vivem e seus bens. Os principais efeitos que atingem os Estados são o rompimento das relações diplomáticas entre os beligerantes e a suspensão dos efeitos de certos tratados entre eles. Terminado o conflito armado, os tratados voltam a vigorar.

E para o término de um conflito armado, o Direito Internacional também tem normas que regulam relações entre os beligerantes. Estas normas, assim como a base para as regras na guerra, foram dadas à doutrina moderna por antigos internacionalistas, principalmente Francisco Suarez e Hugo Grotius. É-nos possível dizer que estas relações entre beligerantes são convenções feitas entre eles que visam o

\footnotetext{
${ }^{34}$ PASSOS, Rodrigo Duarte Fernandes. Clausewitz e a Política - Uma Leitura de "A Guerra". Tese apresentada ao Programa de Pós-graduação em Ciência Política do Departamento de Ciência Política da FFLCH. São Paulo, 2006.p. 8
} 
fim do estado de guerra. Sobre estas convenções especiais, ensina Celso D. de Albuquerque Mello que:

Estas convenções se distinguem dos tratados internacionais comuns em vários pontos: não são concluídas geralmente pelos órgãos normais do Estado para as relações internacionais, mas pelo comandante chefe das forças armadas. Elas se distinguem dos tratados quanto à sua execução, não havendo assim necessidade, por exemplo, de uma promulgação das normas internacionais no âmbito interno. Elas geram obrigações diretamente para o Estado e são executadas pelos órgãos militares. Elas entram em vigor imediatamente após sua conclusão. ${ }^{35}$

Assim, no espelho do que foi a Paz de Westphalia, tratados sempre surgem para colocar término a uma guerra. Estes tratados colocam fim a questões antes divergentes.

Como a guerra atualmente é vista no geral como um meio não lícito para se resolver conflitos entre Estados, o Direito Internacional adota então o que é conhecido como soluções pacíficas de controvérsias internacionais. Uma interessante crítica no estabelecimento da segurança coletiva no sistema Nações Unidas faz Higgins:

O sistema Nações Unidas foi criado para resolver este temível dilema de uma maneira totalmente além de Grotius. No coração da Carta estava a ideia que seria realista para obrigar os Estados a usar a força apenas em legítima defesa, porque a segurança coletiva poderia ser provida para garantir que direitos não poderiam ser negados de forma que pudesse ameaçar a paz internacional. A realidade é que o sistema de segurança coletiva da ONU é totalmente falho. É de fundamental importância reconhecer isso e focar nossas mentes nas consequências decorrentes dessa realidade. Desde o começo as Nações Unidas tem sido incapaz de conter as conter as forças pelas quais foi previsto que o Conselho de Segurança poderia prover a segurança coletiva. ${ }^{36}$

É possível enxergar a questão da guerra de maneira mais fácil levando-se em conta também o Conselho de Segurança da ONU. Como órgão responsável pelas

\footnotetext{
${ }^{35}$ MELLO, Celso D. De Albuquerque. Curso de Direito Internacional Público.13 ed. p.1517-1518

${ }^{36}$ HIGGINS, Rosalyn.Grotius and the Developtment of International Law in the United Nations Period. In: BULL, Hedley; KINGSBURY, Benedict; ROBERTS, Adam. Hugo Grotius and International Relations. Clarendon Paperbacks, 1992, p. 270.
} 
deliberações do uso da força da Organização das Nações Unidas, é de suma importância analisar sua intervenção em alguns conflitos armados em tese.

Pode ser considerada legal o uso da força em casos de legítima defesa do Estado a um ataque armado de outro. Além desta situação, não é considerado ilícito o conflito armado quando autorizada intervenção militar pelo Conselho de Segurança, autorização esta que pode resultar de grave violação aos Direitos Humanos e violação do regime democrático quando for este regime aquele que é de vontade do povo do Estado em questão.

Segundo a Carta da ONU de 1945, em seu capítulo VII, o Conselho de Segurança pode intervir nos casos em que for necessário o uso de força militar nas duas situações anteriormente ditas. É apenas necessário um veto de um dos cinco membros permanentes (Reino Unido, Estados Unidos, China, Rússia e França) para se impedir uma intervenção. Também são necessários nove votos dos quinze componentes para se aprovar uma medida desta, sendo que um dos cinco membros permanentes não vote contra. Se um dos membros for omisso na votação ou desta se ausentar, não será esta omissão considerada um veto, porém é preciso a aprovação da maioria absoluta dos membros para a tomada de qualquer medida.

A existência de qualquer ameaça à paz internacional, ruptura da paz ou ato de agressão será determinada pelo Conselho de Segurança, que, a fim de manter a paz e a segurança internacionais, fará as recomendações ou adotará as medidas que considere apropriadas (artigos 39 a 51$)^{37}$.

No Século XX, após a criação da ONU, foram conhecidos casos em que foi necessária a intervenção: Guerra das Coréias (1950), Rodésia do Sul (1966), Iraque (1991) e Bósnia-Herzegovina (1995). Não convém neste estudo aprofundar nestas questões particulares, mas em todas elas houve a intervenção do Conselho de Segurança por uma das duas razões que a autoriza, seguindo o procedimento estabelecido na Carta. Houve uma gradativa evolução na atuação do Conselho de Segurança após o término da chamada Guerra Fria. Segundo Michael Byers:

Na década de 1990, o conselho de segurança da ONU considerou que certas crises de caráter nacional envolvendo questões humanitárias e de direitos humanos

37 ACCIOLY, Hildebrando; NASCIMENTO E SILVA, Geraldo Eulálio do; CASELLA, Paulo Borba. Manual de Direito Internacional Público. 16ª. ed. ref. São Paulo: Saraiva, 2008, p.417. 
constituíam 'ameaças à paz e à segurança internacionais', justificando assim o recurso ao Capítulo VII para impor sanções ou autorizar o emprego da força militar. ${ }^{38}$

Considerando que o Direito precisa ser comum a todos os povos, as intervenções podem até ter um liame de justiça, já que há uma clara distinção ideológica e política entre, por exemplo, Estados Unidos e Rússia. Uma ação que seja absurdamente ofensiva à liberdade e à integridade dos seres humanos de alguns Estados a ponto de provocar repugnância a rivais políticos dá azo ao uso da força da ONU de maneira que não seja injusta.

\section{CONSIDERAÇÕES FINAIS}

Hugo Grotius foi um dos mais significativos pensadores do direito internacional na emergência da modernidade. O direito internacional pensado como vinculo de confiança entre soberanos dessacralizou o exercício da guerra e possibilitou o surgimento de um modelo de sociedade internacional que se perpetuou durante quase trezentos anos, sendo modificado pelo modelo Nações Unidas, em vigor desde 1945.

Ainda sim, apesar do modelo westphaliano não estar mais em voga atualmente na sociedade internacional - a despeito do debate profundo que o assunto envolve, a posição é de uma mudança de paradigma com a emergência das Nações Unidas muito da compreensão do contemporâneo direito internacional depende dessas bases modernas lançadas no Século XX. Inclusive nesse sentido, é possível revisitar algumas ideias de Grotius em institutos internacionais.

O imutável direito natural racionalizado, passível de ser conhecido pelo homem, que envolve a natureza das coisas em si, pode ser pensado na ideia de imutabilidade de certas normas do direito internacional contemporâneo, principalmente no tocante ao instituto do jus cogens, apesar das diferenças ontológicas entre esses dois conceitos. O jus cogens é um direito (quase) imutável, como o direito natural de Grotius. Também o jus cogens é aplicado de forma geral a toda a sociedade internacional, tal como o direito natural de Grotius aplicado a todas as nações, ou a maioria das nações ditas como civilizadas.

\footnotetext{
${ }^{38}$ BYERS, Michael. A Lei da Guerra. São Paulo: Record, 20o6, p.40.
} 


\title{
SOME OBSERVATIONS ON THE INFLUENCE OF HUGO GROTIUS'S THINKING IN CONTEMPORARY INTERNATIONAL LAW
}

\begin{abstract}
The presented article reports some of the influences of rationalistic thought of the dutch jurist Hugo Grotius (1583-1645) in contemporary international law, which remain even after the entry into force of the United Nations system, to supplant the westphalian system of international law. For this, we present some initial considerations about the Thirty Years' War (1618-1648), sparked of political tension between Catholics and Protestants orginating from the previous century, and its outcome, the Peace of Westphalia , a watershed in the history of international law . Later we talk about the rationalist thought of Grotius, his innovation in thinking an immutable natural law independent of divine law and how he thought the question of justice in war . Finally, as will be discussed some jusracionalist ideas of Grotius can be found in contemporary international law setting, with emphasis on feature ( almost) immutability of jus cogens and the collective security system of the United Nations .
\end{abstract}

Keywords: Hugo Grotius; International Law; Jusracionalism.

\section{REFERÊNCIAS BIBLIOGRÁFICAS}

ACCIOLY, Hildebrando; NASCIMENTO E SILVA, Geraldo Eulálio do; CASELLA, Paulo Borba. Manual de Direito Internacional Público. 16ạ. ed. ref. São Paulo: Saraiva, 2008

BYERS, Michael. A Lei da Guerra. São Paulo: Record, 2006.

FARAGO, France. A Justiça. Barueri: Manole, 2005

FILOMENO, José Geraldo Brito. Manual de Teoria Geral do Estado e Ciência Política. $3^{\circ}$

ed. Rio de Janeiro: Forense Universitária,1999

FIORATI, Jete Jane. Jus Cogens: As Normas Imperativas do Direito Internacional Público como Modalidade Extintiva dos Tratados Internacionais. Franca: Ed. Unesp, 2004.

FLOH, Fabio. Direito Internacional Contemporâneo: Elementos para a Configuração de um Direito Internacional na Ordem Internacional Neo-Vestfaliana. In: CASELLA, Paulo Borba. et al.(org.) Direito Internacional, Humanismo e Globalidade. São Paulo: Atlas, 2009. 
GROTIUS, Hugo. O Direito da Guerra e da Paz. Ijuí: Unijuí, 2007

HIGGINS, Rosalyn. Grotius and the Developtment of International Law in the United Nations Period. In: BULL, Hedley; KINGSBURY, Benedict; ROBERTS, Adam. Hugo Grotius and International Relations. Clarendon Paperbacks, 1992.

KEEGAN, John. Uma História da Guerra. São Paulo: Cia das Letras, 2006.

KINGSBURY, Benedict; ROBERTS, Adam. Introduction: Grotian Thougth in International Relations. In: BULL, Hedley; KINGSBURY, Benedict; ROBERTS, Adam. Hugo Grotius and International Relations. Clarendon Paperbacks, 1992

LIZIERO, Leonam Baesso da Silva. Jus Cogens, Nações Unidas e Direito Bélico. Rio de Janeiro: Agbook, 2013.

MAZZUOLI, Valério de Oliveira. Curso de Direito Internacional Público. 3 ed. São Paulo: RT, 2009

PASSOS, Rodrigo Duarte Fernandes. Clausewitz e a Política - Uma Leitura de "A Guerra”. Tese apresentada ao Programa de Pós-graduação em Ciência Política do Departamento de Ciência Política da FFLCH. São Paulo, 2006.

ROMANO, Roberto. A Paz de Vestfália (1648) In: Demétrio MAGNOLI. (org.). História da

Paz. São Paulo: Contexto, 2007.

SOARES, Guido Fernando Silva. Curso de Direito Internacional Público. São Paulo: Atlas,

2002.

WALTZ, Kenneth N. O Homem, o Estado e a Guerra. São Paulo, Martins Fontes, 2005. WEDGWOOD, C.W. The Thirty Years War. New York: New York Review Book, 2005

WIGHT, Martin. Four Seminal Thinkers in International Theory: Machiavelli, Grotius, Kant and Mazzini. New York: Oxford University Press, 2005.

Trabalho enviado em 19 de agosto de 2014.

Aceito em 11 de fevereiro de 2015. 